\title{
The energy expenditure in the 5 types of modern tennis players
}

\author{
Fabrizio Senatore ${ }^{\mathrm{a}} \&$ Roberto Cannataro ${ }^{\mathrm{b}}$ \\ ${ }^{a}$ Italian Tennis Federation, Trentino, Italy ${ }^{\mathrm{b}}$ University of Calabria, Arcavacata, Province of Cosenza, Italy.
}

\section{ABSTRACT}

This project analyzes and categorizes the 5 types modern tennis players: striker from the baseline, counterattack from the baseline, complete in all court, serve and volley, attacking player, through the assessment of body hydration, energy expenditure, and matches statistics.
Key words: tennis, energy expenditure, metabolic Holter, bioimpedentiometry.

Received: 06 March 2019

Accepted: 20 June 2019

Corresponding author: Fabrizio Senatore, Italian Tennis Federation, Roberto Lombardi Higher Training Institute, Trentino, Italy. Email: senfab@libero.it

\section{INTRODUCTION}

To the best of our knowledge, this is the first scientific study on the energy expenditure of the 5 types of player in modern tennis: striker from the baseline, counterattack from the baseline, complete in all court, serve and volley, attacking player. In order to address our aim, we used 3 technological instruments: the "DF-50 Impedimed" bioimpedenziometer, the "SenseWear armband BodyMedia" metabolic holter and the "Score Analyzer for Tennis" smartphone app.

First, the bioimpedenziometer, a professional non-invasive instrument, was used to analyze the athletes' body composition and the distribution of intra and extracellular fluids. The analysis performed before the tennis match provided with the athlete's current state of health, while the analysis performed after the match, determined how much each athlete lost in terms of body hydration. Then, throughout the use of the metabolic Holter, applied to the triceps of the athlete's arm, we evaluated the total kcal consumed during the match at the best of 3 sets ( 2 sets out of 3 ). Furthermore, with the aid of the graphical analysis, we also observed the duration and time spent sitting at the changes of court, the intensity and the skin temperature of the athlete. To the best of our knowledge, except for the sport of volleyball (Woodruff, Meloche 2013) and rugby (Zanetti et al., 2014), the metabolic holter, has not been used as scientific tool to assess the energy expenditure of tennis players.
Finally, the smartphone app "Score Analyzer for Tennis", cataloged all the statistics of the matches, in order to determine the type of player analysed.

\section{INSTRUMENTS AND METHOD}

Subjects

We tested 50 tennis players, including 25 males and 25 females, aged between 14 and 28 years.

Their tennis activities ranged from 4 to 6 times a week with their ranking between 2.2 and 3.3 of the Italian Tennis Federation classification table.

Instruments

We used 3 scientific instruments:

1. The "DF-50 Impedimed" bioimpedenziometer to measures the impedance of the body to the passage of a low power high frequency electrical current (ca. $50 \mathrm{kHz}$ ). This provides accurate data on the total lipid mass (triglycerides) of the body, lean mass consisting of skeletal muscles (about 40\%), non-skeletal muscles, lean tissues and organs (about 35\%), skeleton (about $10 \%$ ), total body water, which represents on average the $60-62 \%$ of the weight for men and the $56-58 \%$ for woman. 
2. The Metabolic Holter "SenseWear armband BodyMedia" measures the body's physiological parameters: heat flow, galvanic skin response, skin temperature, room temperature proximal to the band, movements through a two-axis and six channels accelerometer. Furthermore, we used the "SenseWear BodyMedia 8.1" software to analyse the total energy expenditure, the active energy expenditure (METs above 3.0), the average METs, the number of steps and total distance covered, and the time spent sitting during court changes for each athlete.

3. The app for Smartphone "Score Analyzer for Tennis" were used to calculate and catalogs all the statistics of tennis matches: as for example, the number of winners, number of forced errors, number of unforced errors, number of aces, number of descents to the net, percentages of first balls "in" at the service, percentages of second balls "in" at the service, percentages of winning returns, etc..

\section{Methodology}

First, we collected the anthropometric data (personal data, family and personal history) for each tennis player. Second, we collected then the anthropometric data (weight, height, body mass index) for each of them. After a complete and accurate collection of all these data, the body composition was measured using the "DF-50 Impedimed" bioimpedenziometer. The distribution of total body fluids, both intra and extracellular, was then detected, thus providing the current health status of the athletes (see Fig. 1).

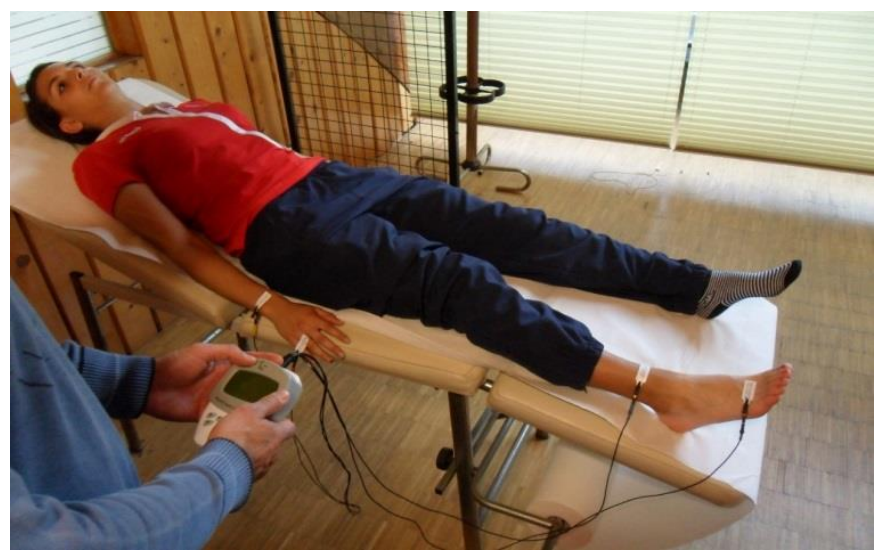

Fig. 1: The figure shows a tennis player, submitted to the bioimpedenziometric exam before the tennis match, scheduled 15 minutes later.

Afterwards, each tennis player was asked to wear the metabolic holter "SenseWear armband BodyMedia" on the triceps of his left arm, to measure all the body's physiological parameters and, therefore, analyze the total energy expenditure (see Fig. 2).

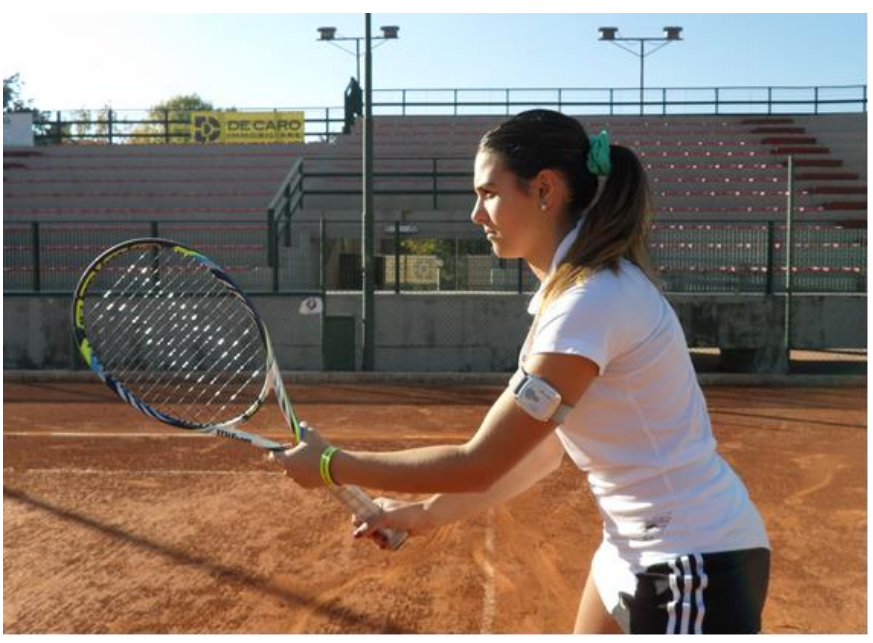

Fig. 2: The figure shows a tennis player with the metabolic holter "SenseWear armband BodyMedia", applied on the triceps of the arm, during a tnnis training session.

With the metabolic holter placed, athletes were asked to play a training match at the best of the 3 sets ( 2 sets out of 3 ), observing all the necessary breaks and changes in the court when scheduled. During the matches, through the smartphone app "Score Analyzer for Tennis" installed on the researcher's smartphone, it was possible to archive all the statistics of the matches, to determine the type of player and have a direct objective analysis of the athlete performances on the playing court.

As soon as the matches were over, we took a second measurement of the players' body composition using the "DF50 Impedimed" bioimpedenziometer) in order to determine the amount of body hydration lost throughout the match.

Each athlete performed 3 measurements, one for each month of activity (January 2018, February 2018, March 2018). All athletes were tested during training session played at the best of the 3 sets ( 2 sets out of 3 ), in outdoor facilities, with an average atmospheric temperature of $19^{\circ} \mathrm{C}$. The matches were held on a single surface, the clay, to compare athlete data on a single playing court; avoiding thus the potential confound for the results obtained on different tennis surfaces (grass, cement and synthetic).

\section{Statistical analyses}

Data were analyzed using the following measures: Hydration and Energy Expenditure (kilocalories) separately for each type of player.

Each measure was entered separately for Male and Female players into an Analysis of Variance (ANOVA) with Type of Players (Striker from the baseline, Counterattack from the baseline, Complete in all court, Serve and volley, Attacking player) as the within-subjects factor. Post-hoc analyses were conducted via pairwise comparisons (t-tests). We used Bonferroni correction for all comparisons. 


\section{RESULTS}

The results point to 3 main categories: body hydration, energy expenditure per hour and types of player. In the next paragraphs, these are described separately for men and women.

Comparison of male body hydration level between the beginning and the end of a match

\begin{tabular}{llll}
\hline Type of Player - Males & Mean & Std. deviation & $\mathrm{N}$ \\
\hline Hard hitter from the baseline & 0.90 & 0.3536 & 5 \\
Counterpuncher from the baseline & 0.30 & 0.1225 & 5 \\
All-court player & 0.79 & 0.3317 & 5 \\
Serve and volleyer & 1.70 & 0.6124 & 5 \\
Attacking player & 2.00 & 0.2828 & 5 \\
Total & 1.12 & 0.7320 & 25 \\
\hline
\end{tabular}

Table 1. Percentage points of men's body hydration lost by players during play

The ANOVA indicated a significant main effect of Type of Players $[\mathrm{F}(4,24)=17.801, \mathrm{p}<.001]$. To assess differences in the hydration level between Types of Players, pairwise comparisons were performed.

\begin{tabular}{|c|c|c|c|c|}
\hline \multicolumn{2}{|c|}{ Difference between: } & \multirow{2}{*}{$\begin{array}{l}\text { mean } \\
\text { diff. } \\
\text { (a)-(b) }\end{array}$} & \multirow{2}{*}{$\begin{array}{l}\text { Std. } \\
\text { error }\end{array}$} & \multirow[t]{2}{*}{ Sig. } \\
\hline Types of players - male (a) & Types of players - male (b) & & & \\
\hline \multirow[t]{4}{*}{$\begin{array}{l}\text { Hard hitter from the } \\
\text { baseline }\end{array}$} & $\begin{array}{l}\text { Counterpuncher from the } \\
\text { baseline }\end{array}$ & 0.600 & 0.237 & 0.201 \\
\hline & All-court player & 0.200 & 0.237 & 1.000 \\
\hline & Serve and volleyer & $-0.800^{*}$ & 0.237 & 0.031 \\
\hline & Attacking player & $-1.100^{*}$ & 0.237 & 0.002 \\
\hline \multirow{4}{*}{$\begin{array}{l}\text { Counterpuncher from the } \\
\text { baseline }\end{array}$} & Hard hitter from the baseline & -0.600 & 0.237 & 0.201 \\
\hline & All-court player & -0.400 & 0.237 & 1.000 \\
\hline & Serve and volleyer & $-1.400^{*}$ & 0.237 & 0.000 \\
\hline & Attacking player & $-1.700^{*}$ & 0.237 & 0.000 \\
\hline \multirow[t]{4}{*}{ All-court player } & Hard hitter from the baseline & -0.200 & 0.237 & 1.000 \\
\hline & $\begin{array}{l}\text { Counterpuncher from the } \\
\text { baseline }\end{array}$ & 0.400 & 0.237 & 1.000 \\
\hline & Serve and volleyer & $-1.000^{*}$ & 0.237 & 0.004 \\
\hline & Attacking player & $-1.300^{*}$ & 0.237 & 0.000 \\
\hline \multirow[t]{4}{*}{ Serve and volleyer } & Hard hitter from the baseline & $0.800^{*}$ & 0.237 & 0.031 \\
\hline & $\begin{array}{l}\text { Counterpuncher from the } \\
\text { baseline }\end{array}$ & $1.400^{*}$ & 0.237 & 0.000 \\
\hline & All-court player & $1.000^{*}$ & 0.237 & 0.004 \\
\hline & Attacking player & -0.300 & 0.237 & 1.000 \\
\hline \multirow[t]{4}{*}{ Attacking player } & Hard hitter from the baseline & $1.100^{*}$ & 0.237 & 0.002 \\
\hline & $\begin{array}{l}\text { Counterpuncher from the } \\
\text { baseline }\end{array}$ & $1.700^{*}$ & 0.237 & 0.000 \\
\hline & All-court player & $1.300^{*}$ & 0.237 & 0.000 \\
\hline & Serve and volleyer & 0.300 & 0.237 & 1.000 \\
\hline
\end{tabular}

$*$ significant difference $(p<0.05)$

Table 2. Pairwise comparisons between different groups of male players for percentage points loss of hydration level during play
Men's energy hourly expenditure

The hourly energy expenditure among the various types of modern tennis player has proved to be quite homogeneous, especially for the men, with the attacking player category showing a slightly higher kilocaloric expenditure compared to the other types of players.

\begin{tabular}{llll}
\hline Type of Player - Males & Mean & $\begin{array}{l}\text { Std. } \\
\text { deviation }\end{array}$ & $\mathrm{N}$ \\
\hline Hard hitter from the baseline & 487 & 19.799 & 5 \\
Counterpuncher from the baseline & 455 & 29.428 & 5 \\
All-court player & 470 & 16.016 & 5 \\
Serve and volleyer & 478 & 15.297 & 5 \\
Attacking player & 525 & 24.779 & 5 \\
Total & 483 & 31.118 & 25 \\
\hline
\end{tabular}

Table 3. Men's hourly energy expenditure (Kcal)

The ANOVA indicated a significant main effect of Type of Players $[F(4,24)=7.296, p<.001]$. To assess differences in the kilocalories between Types of Players, pairwise comparisons were used.

\begin{tabular}{|c|c|c|c|c|}
\hline \multicolumn{2}{|c|}{ Difference between: } & \multirow{2}{*}{$\begin{array}{l}\text { mean } \\
\text { diff. } \\
\text { (a)-(b) }\end{array}$} & \multirow{2}{*}{$\begin{array}{l}\text { Std. } \\
\text { error }\end{array}$} & \multirow[t]{2}{*}{ Sig. } \\
\hline Types of players - male (a) & Types of players - male (b) & & & \\
\hline \multirow[t]{4}{*}{$\begin{array}{l}\text { Hard hitter from the } \\
\text { baseline }\end{array}$} & $\begin{array}{l}\text { Counterpuncher from the } \\
\text { baseline }\end{array}$ & 32 & 13.748 & 0.305 \\
\hline & All-court player & 19 & 13.748 & 1.000 \\
\hline & Serve and volleyer & 9 & 13.748 & 1.000 \\
\hline & Attacking player & -38 & 13.748 & 0.120 \\
\hline \multirow{4}{*}{$\begin{array}{l}\text { Counterpuncher from the } \\
\text { baseline }\end{array}$} & Hard hitter from the baseline & -32 & 13.748 & 0.305 \\
\hline & All-court player & -15 & 13.748 & 1.000 \\
\hline & Serve and volleyer & -23 & 13.748 & 1.000 \\
\hline & Attacking player & $-70^{*}$ & 13.748 & 0.001 \\
\hline \multirow[t]{4}{*}{ All-court player } & Hard hitter from the baseline & -17 & 13.748 & 1.000 \\
\hline & $\begin{array}{l}\text { Counterpuncher from the } \\
\text { baseline }\end{array}$ & 15 & 13.748 & 1.000 \\
\hline & Serve and volleyer & -8 & 13.748 & 1.000 \\
\hline & Attacking player & $-55^{*}$ & 13.748 & 0.001 \\
\hline \multirow[t]{4}{*}{ Serve and volleyer } & Hard hitter from the baseline & -9 & 13.748 & 1.000 \\
\hline & $\begin{array}{l}\text { Counterpuncher from the } \\
\text { baseline }\end{array}$ & 23 & 13.748 & 1.000 \\
\hline & All-court player & 8 & 13.748 & 1.000 \\
\hline & Attacking player & $-47^{*}$ & 13.748 & 0.027 \\
\hline \multirow[t]{4}{*}{ Attacking player } & Hard hitter from the baseline & 38 & 13.748 & 0.120 \\
\hline & $\begin{array}{l}\text { Counterpuncher from the } \\
\text { baseline }\end{array}$ & $70^{*}$ & 13.748 & 0.001 \\
\hline & All-court player & $55^{\circ}$ & 13.748 & 0.007 \\
\hline & Serve and volleyer & $47^{*}$ & 13.748 & 0.027 \\
\hline
\end{tabular}

Table 4. Pairwise comparisons between game styles for men's hourly energy expenditure (Kcal) 
Comparison of female body hydration level between the beginning and the end of a match

\begin{tabular}{llll}
\hline Type of Player - Females & Mean & $\begin{array}{l}\text { Std. } \\
\text { deviation }\end{array}$ & $\mathrm{N}$ \\
\hline Hard hitter from the baseline & 1.40 & 0.2070 & 8 \\
Counterpuncher from the baseline & 0.60 & 0.1195 & 8 \\
All-court player & 1.00 & 0.1852 & 8 \\
Total & 1.00 & 0.3730 & 24 \\
\hline
\end{tabular}

Table 5. Percentage points of female's body hydration lost by players during play

The ANOVA indicated a significant main effect of Type of Players $[\mathrm{F}(2,23)=42.000, \mathrm{p}<.001]$. To assess differences in the hydration level between Types of Players, pairwise comparisons were performed.

\begin{tabular}{|c|c|c|c|c|}
\hline \multicolumn{2}{|c|}{ Difference between: } & \multirow{2}{*}{$\begin{array}{l}\text { mean } \\
\text { diff. } \\
\text { (a)-(b) }\end{array}$} & \multirow{2}{*}{$\begin{array}{l}\text { Std. } \\
\text { error }\end{array}$} & \multirow[t]{2}{*}{ Sig. } \\
\hline Types of players - female (a) & Types of players - female (b) & & & \\
\hline \multirow[t]{2}{*}{$\begin{array}{l}\text { Hard hitter from the } \\
\text { baseline }\end{array}$} & $\begin{array}{l}\text { Counterpuncher from the } \\
\text { baseline }\end{array}$ & $0.800^{*}$ & 0.087 & 0.000 \\
\hline & All-court player & $0.400^{*}$ & 0.087 & 0.000 \\
\hline \multirow[t]{2}{*}{$\begin{array}{l}\text { Counterpuncher from the } \\
\text { baseline }\end{array}$} & $\begin{array}{l}\text { Hard hitter from the } \\
\text { baseline }\end{array}$ & $-0.800^{*}$ & 0.087 & 0.000 \\
\hline & All-court player & $-0.400^{*}$ & 0.087 & 0.000 \\
\hline \multirow[t]{2}{*}{ All-court player } & $\begin{array}{l}\text { Hard hitter from the } \\
\text { baseline }\end{array}$ & $-0.400^{*}$ & 0.087 & 0.000 \\
\hline & $\begin{array}{l}\text { Counterpuncher from the } \\
\text { baseline }\end{array}$ & $0.400^{*}$ & 0.087 & 0.000 \\
\hline
\end{tabular}

* = significant difference $(p<0.05)$

Table 6. Pairwise comparisons between different groups of female players for percentage points loss of hydration level during play

Female's energy hourly expenditure

As explained in the introduction of this paper, the female players did not include two types of player: the "serve and volley" and the "attacking player". Thus, in the following paragraphs we will detail the results obtained for three types of players only.

\begin{tabular}{llll}
\hline Type of Player - Females & Mean & $\begin{array}{l}\text { Std. } \\
\text { deviation }\end{array}$ & $\mathrm{N}$ \\
\hline Striker from the basel ine & 390 & 15.119 & 8 \\
Counterattacker from the baseline & 322 & 10.770 & 8 \\
Complete all-court & 275 & 8.177 & 8 \\
Total & 329 & 49.505 & 24 \\
\hline
\end{tabular}

\section{Table 7. Female's hourly energy expenditure}

The ANOVA indicated a significant main effect of Type of Players $[\mathrm{F}(2,23)=195.008, \mathrm{p}<.001]$. To assess differences in the kilocalories between Types of Players, pairwise comparisons were used.

\begin{tabular}{|c|c|c|c|c|}
\hline \multicolumn{2}{|c|}{ Difference between: } & \multirow{2}{*}{$\begin{array}{l}\text { mean } \\
\text { diff } \\
\text { (a)-(b) }\end{array}$} & \multirow{2}{*}{$\begin{array}{l}\text { Std. } \\
\text { error }\end{array}$} & \multirow[t]{2}{*}{ Sig. } \\
\hline Types of players - female (a) & Types of players - female (b) & & & \\
\hline \multirow[t]{2}{*}{$\begin{array}{l}\text { Hard hitter from the } \\
\text { baseline }\end{array}$} & $\begin{array}{l}\text { Counterpuncher from the } \\
\text { baseline }\end{array}$ & $68^{*}$ & & 0.000 \\
\hline & All-court player & $115^{*}$ & & 0.000 \\
\hline \multirow[t]{2}{*}{$\begin{array}{l}\text { Counterpuncher from the } \\
\text { baseline }\end{array}$} & $\begin{array}{l}\text { Hard hitter from the } \\
\text { basel ine }\end{array}$ & $-68^{*}$ & & 0.000 \\
\hline & All-court player & $47^{*}$ & & 0.000 \\
\hline \multirow[t]{2}{*}{ All-court player } & $\begin{array}{l}\text { Hard hitter from the } \\
\text { baseline }\end{array}$ & $-115^{*}$ & & 0.000 \\
\hline & $\begin{array}{l}\text { Counterpuncher from the } \\
\text { baseline }\end{array}$ & $-47^{*}$ & & 0.000 \\
\hline
\end{tabular}

* significant difference ( $p<0.05)$

Table 8. Pairwise comparisons between different types of female players for hourly energy expenditure (Kcal)

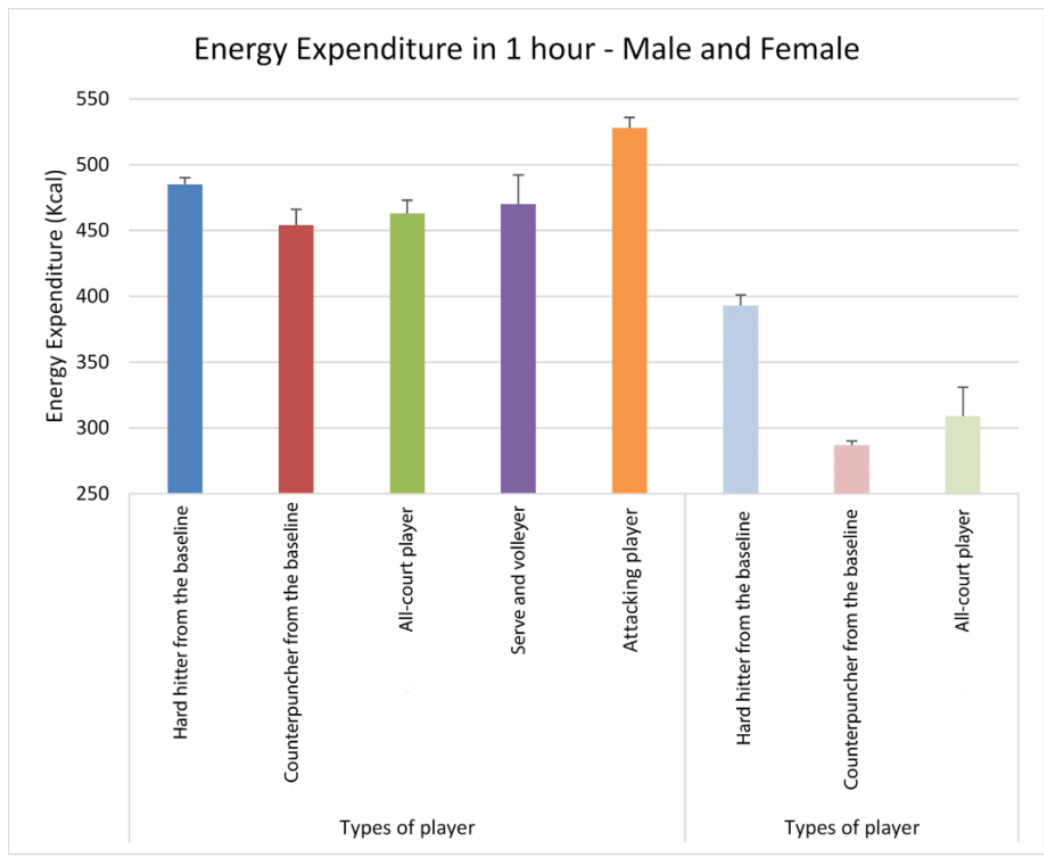

Fig. 3: The graph shows the comparison of the energy expenditure (kcal) hours during the matches between the various types of player, divided between males and females. The bars represent the standard deviation from the average.

\section{CONCLUSIONS}

The present work scientifically highlights for the first time the energy expenditure in the 5 types of player in of modern tennis players, for both male and female sectors. To this aim, we measured, analyzed and then evaluated the differences in the hydration level between the beginning and the end of a match, the different energy consumption per hour and we provided each player with a specific type of training scheme. In particular, those players that evidenced a high energy expenditure level in the first measurement (January 2018), received detailed indications on how to improve their 
nutritional lifestyle, physical preparation and tactics used during the match, aiming to improve their overall performance. For instance, to the counterattack from the baseline who showed high energy expenditure levels, we suggested two strategies: the first pointed to a radical change in the athlete physical preparation and nutrition habit, so as to achieve better performance in strength and resistance; the second strategy pointed to a variation of the style of play, including more variability so as to increase the number of winning shots.

It is worth noting that these strategies have been addressed considering (technical, tactical, physical, mental aspects) and, as such, were customized for each subject based on the athlete daily training and nutritional lifestyle.

The second and third measurements (February 2018 and March 2018) showed a general improvement of the player abilities, succeeding in concluding the exchanges during the match with more possible solutions and with a lower energy expenditure.

Moreover, the results evidenced a significant difference in the body hydration level measured at the beginning and the end of each match, for both male and female, which had a strong impact on the match results. In fact, the $75 \%$ of players that won a match showed a negative variation of total body fluids equal to $<1 \%$. This result corroborates the importance of hydration before, during and after a match or a tennis training. Furthermore, as evidenced in the results section, female in all court players showed a reduced energy expenditure (ca. 200 Kcal) compared to male players belonging to the same category in 1 hour of match (see Fig. 3). This underlines the importance of customizing a specific physical and nutritional model for each player, thus pointing to a general improvement of the athlete health and lifestyle.

In conclusion, these data represent a point of strength for each tennis coach to scientifically guide his athletes to a specific type of player in modern tennis, based on the analysis of body and tactic measurements, and considering individual skills and attitudes of the athlete towards the chosen style.

\section{REFERENCES}

Bollettieri N., Nick Bollettieri's tennis handbook $-2^{\text {nd }}$ edition, Leeds, ed. Human Kinetics, 2015, 150-165.

Bollettieri N., The 5 keys to tennis: a universal language for tennis learning, Sarasota, ed. NBTA, Inc., 1992, 58-65. Clerici G., 500 anni di tennis, Milano, ed. Mondadori, 2007, 78-80.

Deldossi L., Paroli R., Lezioni di statistica, Torino, ed. Giappichelli, 2010, 59-62.

Gallwey T., The inner game of tennis: the classic guide to the mental side of peak performance, New York, Random House Trade Paperbacks, 2008, 25-26.

Giampietro M., L'alimentazione per l'esercizio fisico e lo sport, Roma, ed. Il pensiero scientifico, 2009, 24-28.

Istituto Superiore di Formazione "Roberto Lombardi"

Federazione Italiana Tennis, La costruzione tattica del tennista moderno, Super Tennis Magazine, 2013, 8-10.

Kovacs M., Roetert P., Ellenbecker T., Complete conditioning for tennis, Leeds, Human Kinetics, 2016, 175-177.
La Guardia M., Giammanco M., Giammanco S., Fondamenti di scienza dell'alimentazione, Napoli, ed. Edises, 2010, 3438.

Lisi R., Tennis e scoliosi stato dell'arte, Roma, ed. Lombardo, 2007, 74-75.

Mariani Costantini A., Cannella C., Tomassi G., Alimentazione e nutrizione umana, Roma, ed. II pensiero scientifico, 2016, 204-208.

McArdle W., Katch F., Katch V., Fisiologia applicata allo sport, Aspetti energetici, nutrizionali e performance, Modena, ed. Zanichelli, 2018, 61-62.

Paul E., Roetert D., Tennis Anatomy, Leeds, ed. Human Kinetics, 2011, 185-190.

Piccoli A., Bioimpedenza clinica, Analisi vettoriale e composizione corporea, Genova, ed. Forum Service, 1999, 87-90.

Sullivan M., Fondamenti di statistica, Milano, ed. Pearson, 2015, 325-326.

Wilmore J., Costill D., Fisiologia dell'esercizio fisico e dello sport, Perugia, ed. Calzetti, Mariucci, 2005, 456-460.

Woodruff S., Meloche R., Energy availability of female varsity volleyball players, The Journal of Sport Nutrition and Exercise Metabolism, 23, 2013, 24-30, https://doi.org/10.1123/ijsnem.23.1.24

Zanetti S., Wheeler K., Validity of the sensewear armband to assess energy expenditure during intermittent exercise and recovery in rugby union players, The Journal Of Strength and Conditioning Research, 28, 2013, 4, https://doi.org/10.1519/JSC.0000000000000243

RECOMMENDED ITF TENNIS ACADEMY CONTENT (CLICK BELOW)

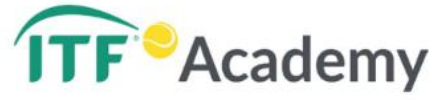

Copyright (c) 2019 Fabrizio Senatore \& Roberto Cannataro

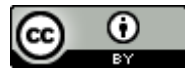

This text is under a Creative Commons BY 4.0 license

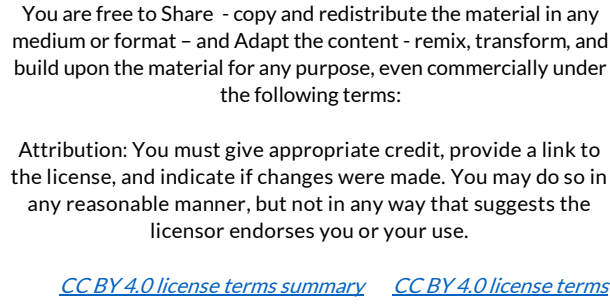

You are free to Share - copy and redistribute the material in any medium or format - and Adapt the content - remix, transform, and build upon the material for any purpose, even commercially under
the following terms:

Attribution: You must give appropriate credit, provide a link to the license, and indicate if changes were made. You may do so in licensor endorses you or your use.

CCBY 4.0license terms summary CCBY4.0 license terms 